\title{
Defining Dysbiosis in Disorders of Movement and Motivation
}

\author{
(1CChristopher T. Fields, ${ }^{1}$ Timothy R. Sampson, ${ }^{2}$ Annadora J. Bruce-Keller, ${ }^{3}$ Drew D. Kiraly, ${ }^{4}$ Elaine Y. Hsiao, ${ }^{5}$ \\ and Geert J. de Vries ${ }^{1}$ \\ ${ }^{1}$ Neuroscience Institute, Georgia State University, Atlanta, Georgia 30303, ${ }^{2}$ Division of Biology \& Biological Engineering, California Institute of Technology, \\ Pasadena, California 91125, ${ }^{3}$ Pennington Biomedical Research Center, Louisiana State University System, Baton Rouge, Louisiana 70808, ${ }^{4}$ Departments of \\ Psychiatry \& Neuroscience, Friedman Brain Institute, Icahn School of Medicine, New York, New York 10029, and ${ }^{5}$ Department of Integrative Biology and \\ Physiology, University of California-Los Angeles, Los Angeles, California 90095
}

The gut microbiota has emerged as a critical player in shaping and modulating brain function and has been shown to influence numerous behaviors, including anxiety and depression-like behaviors, sociability, and cognition. However, the effects of the gut microbiota on specific disorders associated with thalamo-cortico-basal ganglia circuits, ranging from compulsive behavior and addiction to altered sensation and motor output, are only recently being explored. Wholesale depletion and alteration of gut microbial communities in rodent models of disorders, such as Parkinson's disease, autism, and addiction, robustly affect movement and motivated behavior. A new frontier therefore lies in identifying specific microbial alterations that affect these behaviors and understanding the underlying mechanisms of action. Comparing alterations in gut microbiota across multiple basal-ganglia associated disease states allows for identification of common mechanistic pathways that may interact with distinct environmental and genetic risk factors to produce disease-specific outcomes.

Key words: gut microbiota; basal ganglia; compulsive behavior; motor function; Parkinson's; addiction

\section{Introduction}

From their earliest origins, eukaryotic cells have had a symbiotic relationship with microbes, which in multicellular organisms cover nearly every surface exposed to the environment, supporting critical aspects of host metabolism and physiology (FrancoObregón and Gilbert, 2017). In humans, an estimated 1:1 to 10:1 ratio of microbial cells for every human cell resides within the body, with the greatest reservoir being in the digestive tract (Sender et al., 2016). This microbial community is not only large by absolute number, but by complexity as well, and consists of myriad bacterial, fungal, viral, and protozoal species. Bacteria outnumber all other members, and of these, the Bacteroidetes and Firmicutes phyla predominate (Rosenbaum et al., 2015). However, broad generalizations about their impact on the host cannot easily be made as different species, and even strains within a specific phylum can differ markedly in physiology and metabolic output (Geva-Zatorsky et al., 2017). In addition, less abundant

\footnotetext{
Received Sept. 5, 2018; revised Sept. 28, 2018; accepted Sept. 28, 2018

This work was supported by National Institute of Health Grants MH112369 to C.T.F., MH110117 to A.J.B.-K., DA044308 to D.D.K., OD017924 to E.Y.H., and MH108345 to G.J.d.V.; the Brain and Behavior Research Foundation to D.D.K.; the Larry L. Hillblom Foundation to T.R.S.; and the Office of Naval Research, Multidisciplinary University Research Initiative to E.Y.H.

The authors declare no competing financial interests.

Correspondence should be addressed to Dr. Christopher T. Fields, Neuroscience Institute, Georgia State University, Atlanta, GA 30303. E-mail: cfields18@student.gsu.edu.

T.R. Sampson's present address: Department of Physiology, Emory University School of Medicine, Emory University, Atlanta, GA 30329.

DOI:10.1523/JNEUROSCI.1672-18.2018

Copyright $\odot 2018$ the authors $\quad 0270-6474 / 18 / 389414-09 \$ 15.00 / 0$
}

and even rare taxa may regulate overall community structure and function and play important roles in host physiology (Jousset et al., 2017; Enaud et al., 2018).

Over the past two decades, an explosion of research has begun to detail the robust relationship between gut microbiota and the CNS. Many of the foundational studies investigating the so-called gut-brain axis were made possible by the generation of germ-free rodents, which are devoid of microbes from birth. These animals demonstrate significant alterations in host physiology and behavior, suggesting that the microbiota communicates critical signals required for normal development (Mazmanian et al., 2005; Ley et al., 2006; Diaz Heijtz et al., 2011; Neufeld et al., 2011). Additional studies have manipulated content by either administering probiotics or antibiotics, or by direct transfer of gut microbiota across model organisms. Such studies have revealed fundamental roles for the gut microbiota in regulating complex host behaviors, including social, stress-induced, and cognitive behaviors (Sudo et al., 2004; Diaz Heijtz et al., 2011; Neufeld et al., 2011; Clarke et al., 2013). More recent studies also point to a role for microbiota in sensory-motor processing, movement disorders such as Parkinson's disease (PD), motivational processes, and substance use disorders (Hsiao et al., 2013; Kiraly et al., 2016; Sampson et al., 2016). Table 1 highlights some experiments that take advantage of wholesale depletion of gut microbiota to begin to investigate the effects of gut microbiota on these disorders, which will be discussed in this review.

To date, much of the work on gut microbial modulation of brain function and output has focused on its effects on cognition, 
Table 1. Effects of microbial depletion on motor function and motivated behavior ${ }^{a}$

\begin{tabular}{|c|c|c|c|c|}
\hline Treatment & Subject & Behavior & Description & Reference \\
\hline Germ-free & C57BL/6 and Swiss-Webster mice, male & Sensorimotor & Decreased activation of intestinal sensorimotor neurons & Yano et al., 2015 \\
\hline Low-dose penicillin & C57BL/6 mice, male + female & Social preference & Increased preference for familiar conspecifics & Leclercq et al., 2017 \\
\hline Germ-free & Swiss-Webster mice, male & Social preference & Increased preference for familiar conspecifics & Desbonnet et al., 2014 \\
\hline High-dose antibiotic mixture & NIH Swiss mice, male & Novel object preference & Increased preference for familiar object & Desbonnet et al., 2015 \\
\hline Germ-free & Swiss-Webster mice, male & Novel object preference & Increased preference for familiar object & Gareau et al., 2011 \\
\hline High-dose antibiotic mixture & C57BL/6 mice, male & Novel object preference & Increased preference for familiar object & Fröhlich et al., 2016 \\
\hline Germ-free & ASO mice (Parkinson's model), male & Motor behavior & $\begin{array}{l}\text { Less robust deficits in time to traverse a beam, descend a pole, } \\
\text { and remove an adhesive from the nasal bridge }\end{array}$ & Sampson et al., 2016 \\
\hline Germ-free & C57BL/6 mice, male & Food consumption & Decreased caloric consumption & Rabot et al., 2010 \\
\hline High-dose antibiotic mixture & C57BL/6 mice, male & Drug-seeking behavior & Increased conditioned place preference & Kiraly et al., 2016 \\
\hline
\end{tabular}

${ }^{a}$ Effects of germ-free status (relative to conventionally colonized mice) or treatment with antibiotics (relative to subjects not treated with antibiotics) on motor function, novelty-seeking behavior, or addiction.

stress, and social behavior, with a large focus on the cortex, hippocampus, hypothalamus, and amygdala (Sudo et al., 2004; Diaz Heijtz et al., 2011; Neufeld et al., 2011; Clarke et al., 2013; Hoban et al., 2018). This review focuses on the basal ganglia, as they play an important role in sensory motor processing and the regulation of habitual movement, which contributes to core features of many neurobehavioral disorders (Figee et al., 2016). We will highlight research that contributes to our understanding of how the gut microbiota affects body movement and compulsive-like behaviors. First, we discuss the role of gut microbiota in regulating sensorimotor circuits and behaviors that depend on these circuits. Next, we review work demonstrating a link between gut microbiota and motor dysfunction in PD. We then highlight work that draws a link between gut microbiota and compulsive behaviors, ranging from tics in autism to complex behaviors in obesity and substance addiction. Finally, we explore common themes that may indicate shared underlying mechanisms in the gut-brain connection that generate dysfunction in basal ganglia circuits.

\section{The gut microbiota and sensorimotor circuits}

The contributions of gut microbiota to sensorimotor functioning in the gut and the brain are beginning to be characterized. For instance, germ-free mice display decreased gastrointestinal sensorimotor activity, as measured by lowered overall levels of gastrointestinal motility (Yano et al., 2015). Notably, treatment of mice with the probiotic Bacteroides fragilis or colonization of mice with a consortium of spore-forming bacteria, was sufficient to correct gastrointestinal function, in a process mediated by microbially induced production of serotonin (Yano et al., 2015). Direct proof that microbiota affect sensory processing in the brain also comes from studies with germ-free mice, which show deficits in sensorimotor gating of the startle reflex, suggesting an inability to filter out extraneous sensory cues (Hsiao et al., 2013). Alterations in gut microbiota in individuals with neuropsychiatric conditions, such as autism and schizophrenia, may therefore contribute to sensorimotor gating deficits observed in these disorders (Hsiao et al., 2013; Kohl et al., 2013; Dinan et al., 2014). As sensorimotor gating is processed within the cortico-basal ganglia circuit, identification of mechanisms of microbial communication to this brain region that affect other aspects of basal ganglia functioning, such as motor function and compulsive behavior, will likely yield clues to how gut microbiota affect this form of sensory processing.

\section{Gut microbiota and motor function}

Work on PD has revealed a link between gut microbiota and motor function. While early studies suggested that the gut microbiota influences motor behavior, as germ-free mice exhibited in- creased locomotion in the open field test (Diaz Heijtz et al., 2011), it was unclear whether such a change depended on direct actions of the microbiota on motor circuits. However, a mouse model for PD revealed direct contributions of gut microbiota to disease onset and progression in behavioral and histological markers for the disorder. PD is a progressive, neurodegenerative disorder characterized by a loss of dopaminergic neurons in the midbrain, specifically within the substantial nigra pars compacta and its projections to the striatum, which impairs the initiation of movements (Hadj-Bouziane et al., 2012). Aggregation of $\alpha$-synuclein has been identified as a central component of PD pathology. PD is generally considered a neuroinflammatory disease in which cytokines generated in the brain, and peripheral immune cells migrating into the brain, promote $\alpha$-synuclein misfolding. However, recent work suggests an additional vagal route for inflammatory agents to promote neuroinflammation (Kannarkat et al., 2013). Injection of aggregates of $\alpha$-synuclein into the intestinal wall of healthy rodents promotes prion-like formation of $\alpha$-synuclein inclusion bodies along the vagus nerve and within afferent brainstem loci, thereby providing a potential pathway to the substantia nigra and dorsal striatum (Holmqvist et al., 2014; Uemura et al., 2018). In support of this, two retrospective studies found that complete vagotomy, but not partial vagotomy, which does not completely denervate vagal connections to the gut, leads to reduced risk of future diagnosis of PD (Svensson et al., 2015; Liu et al., 2017). While the function of $\alpha$-synuclein remains unclear, it is of note that it is present within the enteroendocrine cells within the gastrointestinal tract (Chandra et al., 2017), and it has been suggested to assist with vesicle trafficking in neurons (Diao et al., 2013). Signals from the gut microbiota may locally induce $\alpha$-synuclein pathology or increase susceptibility to other genetic or environmental risk factors (e.g., pesticides) that promote pathological $\alpha$-synuclein misfolding (Brown et al., 2006).

Work by Sampson et al. (2016) points to a critical role of gut microbes in PD pathology. Thy1- $\alpha$-synuclein mice ("Line 61"), which overexpress wild-type human $\alpha$-synuclein, also known as $\alpha$-synuclein overexpressing (ASO) mice, were protected from developing $\alpha$-synuclein pathology and motor symptoms when bred under germ-free conditions. Colonization with fecal microbes from control mice and healthy human subjects both produced impaired motor function in germ-free ASO mice. However, colonizing mice with fecal microbes derived from PD patients worsened motor outcomes. This suggests that, while gut microbiota facilitates disease pathology, at least in genetically susceptible individuals, the specific microbes found in persons with PD may exacerbate disease outcomes.

Fecal microbiota collected from persons with PD, and subsequently colonized into germ-free mice, exhibited increased abundance of the Gram-negative Proteobacteria phylum and reduced 
levels of spore-forming Lachnospiricae family and Ruminococcus genus of the Firmicutes phylum (Sampson et al., 2016). Similar changes to the microbiota are observed in other studies of PD patients, which are reviewed by Tremlett et al. (2017) and Sun and Shen (2018). However, no two studies report identical changes in microbiota. Some studies note increases in specific Clostridial species or species within the Firmicutes phylum (Bedarf et al., 2017; Hill-Burns et al., 2017; Heintz-Buschart et al., 2018; Qian et al., 2018), whereas others report decreases in clusters of Clostridial species (Hasegawa et al., 2015; Scheperjans et al., 2015; Hill-Burns et al., 2017; Li et al., 2017). Clostridia is a class of the Firmicutes phylum that contains a large number of sporeforming species that promotes serotonin production in the body (Yano et al., 2015), which may drive systemic inflammation (Patrick and Ames, 2015). However, some studies report an increase in Lactobacillus in PD patients (Minato et al., 2017; Petrov et al., 2017), a genus of the Firmicutes phylum that contains species commonly used to reduce inflammation in a number of autoimmune disease models (Plaza-Díaz et al., 2017). Potentially confounding effects across study cohorts, such as differences in drug treatment and dietary habits, may drive some of these discrepancies. However, they may also reflect specific changes within the genus level that may go undetected by the bacterial sequencing methods (e.g., 16S rRNA sequencing) used in these studies, and large-scale metagenomic analysis may provide a clearer indication of dysbiosis in PD (Poretsky et al., 2014).

Gut microbiota might contribute to several factors that promote $\alpha$-synuclein misfolding in the basal ganglia, including direct vagal transmission of the misfolded protein. In the work of Sampson et al. (2016), neuroinflammation in specific-pathogenfree ASO mice was observed in the frontal cortex and striatum, but not in the cerebellum. Gut microbiota might stimulate vagal efferents to produce this effect, given that vagal nerve stimulation in rats has its most robust biophysical effects across a limited number of midbrain and forebrain areas, including the basal ganglia (Surowka et al., 2015). Additionally, it might be that toxins produced by the microbiota have differential access to different brain regions depending on the permeability of the blood-brain barrier (Yang and Chiu, 2017). Regions of the basal ganglia are situated near regions of the blood-brain barrier that are particularly leaky in PD patients (Gray and Woulfe, 2015). Regardless of the means of transmission, gut microbiota play a critical role in driving pathology in this rodent model of PD and may play an influential role in the etiology of this disease in humans as well.

\section{Gut microbiota and repetitive behaviors}

Just as components of gut microbiota may impair normal initiation of motor function, they might also affect the basal ganglia's ability to prevent behaviors, allowing the development of tics and other repetitive behaviors (Bronfeld and Bar-Gad, 2013). Fields et al. (2018b) showed that increased intestinal load of lipopolysaccharides, an inflammatory antigen derived from Gramnegative bacteria, influences repetitive behaviors. Small intestinal bacterial overgrowth is a condition wherein Gram-negative bacteria and anaerobes are overly abundant, leading to inflammatory bowel syndrome and related anxiety disorders (Posserud et al., 2007; Popa and Dumitrascu, 2015). We used oral gavage delivery of exogenous lipopolysaccharide into adult mice as a proxy for small intestinal bacterial overgrowth driven by overgrowth of Gram-negative bacteria. This treatment suppressed normal levels of repetitive circling in the open field test, without affecting general measures of locomotion, suggesting that the lipopolysaccharide treatment specifically affects compulsive behaviors without inducing a generalized sickness response (Fields et al., 2018b). In line with this, germ-free mice, which have no lipopolysaccharide, exhibit increases in compulsive-like behavior, such as repetitive digging (Nishino et al., 2013). Studying specific changes of gut microbiota in conditions that exhibit changes in locomotor and habit circuits may yield substantial clues to other bacterial components that actively modulate basal ganglia circuits.

Gut microbial changes reported in individuals with autism spectrum disorder (ASD) and in rodent models of this disorder provide further clues regarding the potential mechanisms through which gut microbiota modulate repetitive behavior. For example, several studies consistently demonstrate elevated levels of Clostridia in fecal samples collected from autistic subjects (Finegold et al., 2002; Song et al., 2004; Parracho et al., 2005; Martirosian et al., 2011; Li and Zhou, 2016; Finegold et al., 2017; Iovene et al., 2017; Vuong and Hsiao, 2017; Argou-Cardozo and Zeidan-Chulia, 2018). Clostridia produce propionic acid, a shortchain fatty acid byproduct of carbohydrate fermentation, which has been proposed to cross the blood-brain barrier and may contribute to the core social and behavioral deficits observed in autism (Shultz, 2014). In support of this, several studies show that intracerebroventricular injection of propionic acid affects autism-related social and cognitive measures, including the inability to activate goal-directed behavior switching in the water maze and T-maze (Shultz et al., 2009; MacFabe et al., 2011). Propionic acid treatment also elevated brain levels of serotonin and dopamine (Shultz et al., 2008, 2009), and induced neuroinflammation across various cortical and subcortical regions, which may contribute to the observed cognitive and behavioral deficits (Shultz et al., 2008, 2009; MacFabe et al., 2011; Shultz, 2014). However, whether the dosages of propionic acid used in these studies reflect levels found in autistic subjects remains to be determined.

If Clostridia and other microbiota species induce behavioral effects in autistic subjects, it will likely result from multiple activation pathways involving immune, humoral, and vagal routes. For example, Clostridia produce several toxic byproducts found in patients with ASD and animal models, including the uremic toxins para-cresol and 4-ethylphenylsulfate, which might also cross the blood-brain barrier and affect cortico-thalamo-basal ganglia circuits (Enomoto and Niwa, 2007; Altieri et al., 2011; Hsiao et al., 2013; Gabriele et al., 2014, 2016). Intravenous injection of 4-ethylphenylsulfate increased marble-burying behavior in juvenile mice (Hsiao et al., 2013) and para-cresol levels correlated with severity of repetitive behaviors in autistic subjects, but not with other symptoms of autism (Gabriele et al., 2014).

Levels for other gut microbial species may also be altered in patients with ASD (Li and Zhou, 2016; Vuong and Hsiao, 2017). While microbiota changes lack consistency from study to study, a unifying mechanism through which gut microbiota affect symptoms of ASD is by modifying the permeability of the gut. For example, as discussed for PD, Prevotella levels are inversely correlated with gut barrier permeability (Brown et al., 2011; Forsyth et al., 2011; Cakmak, 2015). In line with this, lower levels of Prevotella correlate with greater burdens of behavioral autistic symptoms (Kang et al., 2013; Krajmalnik-Brown et al., 2015; Strati et al., 2017; Kang et al., 2018; Qiao et al., 2018). Nevertheless, some clinical studies do not find this correlation between Prevotella and autism symptoms (Son et al., 2015; Strati et al., 2017). Another model for ASD, the maternal immune activation model of autism, shows an increase in Prevotella. However, this model also demonstrates increased gut permeability and a treat- 
ment that restored the integrity of the gut barrier also normalized anxiety and repetitive behavior (Hsiao et al., 2013).

Other findings highlight the importance of investigating functional output of the gut microbiota in addition to identifying key taxa associated with ASD. For example, some studies report an increase in Sutterella, a member of the Proteobacteria phylum that may contribute to gut barrier dysfunction and systemic endotoxemia in autistic subjects (Williams et al., 2012; Wang et al., 2013); however, these findings are not reported in other studies (Strati et al., 2017; Qiao et al., 2018). Elevated levels of Lactobacillus species are also reported for children with ASD (Kang et al., 2013; Pulikkan et al., 2018); however, one open label clinical study successfully used Lactobacillus species to treat gastrointestinal and behavioral symptoms (Shaaban et al., 2017). These seemingly contradictory studies may be explained by separate bacterial strains within the same species having unique physiological and behavioral effects (Merkx-Jacques et al., 2013; Proença et al., 2017). Thus, it is important to screen for overall functional output of microbiota rather than simply noting compositional differences. This may also help researchers identify which microbial changes contribute to behavioral symptoms or may be endogenous compensatory mechanisms.

\section{Gut microbiota and compulsive behaviors}

Compulsive behaviors are observed not just across a wide spectrum of neuropsychiatric disorders, but also in behaviors not traditionally associated with neuropsychiatric disorders, such as compulsive eating. Compulsive eating may contribute to the pathophysiology of obesity in a subset of individuals (Moore et al., 2018). Obese individuals exhibit significant comorbidity with obsessive-compulsive disorder (Albert et al., 2013), along with several neurobiological markers of addiction, including increased cortico-striatal connectivity, and impaired dopamine regulation of the orbitofrontal cortex and dorsal striatum (Volkow et al., 2008, 2013; Cone et al., 2013). While the gut microbiota participates in nutrient energy harvesting and plays a role in many other aspects of host metabolism (Pascale et al., 2018), it may also drive compulsive eating. Transfer of microbiota from obese mice to those raised on a standard diet conferred many of the phenotypes observed in high-fat diet fed mice. Mice that received transfer of a microbiome from high-fat diet-fed mice showed significant propensity to become obese. Although feeding behavior itself was not measured, these mice showed increases in anxiety-like behavior on the open field test and elevated plus maze and increases in compulsive-like burying behavior in the marble-burying test. (Bruce-Keller et al., 2015).

Another set of psychiatric disorders marked by compulsive behavior in humans are the substance use disorders. Recent work has found that the gut microbiota both influences and is influenced by the effects of psychostimulant drugs and may contribute to compulsive substance use. Kiraly et al. (2016) showed that antibiotic depletion of gut microbiota in adulthood leads to increased sensitivity to the behavioral effects of cocaine in mice. Antibiotic treatment increased the development of locomotor sensitization and conditioned place preference at a dose that did not produce behavioral effects in control animals. Antibiotic treatment increased striatal expression of BDNF, a neuropeptide with wide-ranging effects on brain physiology, regardless of cocaine exposure. The increase in BDNF may serve as a trigger for downstream neurochemical effects, as both cocaine and antibiotic treatments were required to elicit changes in glutamate and dopamine receptor expression. These observations demonstrate that the gut microbiota acutely influences function and output of systems that encode motivational salience and mediate decisionmaking (Kiraly et al., 2016).

\section{Putting the pieces together}

The studies discussed in this review highlight similarities and differences in gut microbiota composition both within and across various basal ganglia-associated disease states, providing as many clues as questions regarding the potential effects of gut microbes on basal ganglia circuits. Changes in gut microbiota could either serve as significant or moderating factors in the etiology of these diseases, or they could simply be interesting epiphenomena. Accumulating evidence points to the former, with wholesale depletion and modification of gut microbiota either ameliorating or worsening disease state in animal models of PD (Sampson et al., 2016), obesity (Bruce-Keller et al., 2015), and cocaine addiction (Kiraly et al., 2016). Alternatively, even if the changes to the microbiota that occur during disease processes are merely a bystander effect, the continued study of these changes may provide benefit as early indicators of disease diagnosis or prognosis.

Microbiota are also required for the normal development of basal ganglia circuits, as evidenced by reduced expression of synapse-related gene expression within the striatum of germ-free mice (Diaz Heijtz et al., 2011). Microbiota actively maintain normal basal ganglia physiology in adult animals, with antibiotic depletion of gut microbiota increasing BDNF expression in the ventral striatum in conventionally colonized mice (Kiraly et al., 2016), potentially with wide-ranging effects (Song et al., 2017). While such studies suggest that microbiota may affect basal ganglia function and behavioral output, the mechanisms underlying these effects remain unknown.

To address this question, it is first important to acknowledge the extensive functional redundancy within gut microbiota (Allison and Martiny, 2008). For example, the Human Microbiome Project revealed that it is possible for two healthy human individuals to share minimal to no overlap in microbial species composition (Gilbert et al., 2018). This functional redundancy may explain some of the contradictory findings of changes in gut microbiota within the diseases discussed here. For example, original studies on gut microbial changes within obese subjects reported increases in the Firmicutes-to- Bacteroidetes ratio in both obese rodents and humans (Ley et al., 2005; Turnbaugh et al., 2006). However, subsequent work either found no changes in this ratio (Duncan et al., 2008; Million et al., 2013; Rosenbaum et al., 2015) or an inverse of this ratio in obese subjects (Schwiertz et al., 2010; Ignacio et al., 2016), along with more fine-grained increases and decreases of species within both the Firmicutes and Bacteroidetes phyla within obese subjects (Bruce-Keller et al., 2015; Jung et al., 2018). Nevertheless, later work also confirmed the finding of an increased Firmicutes-to-Bacteroidetes ratio in some obese subjects, suggesting that this compositional change may serve as a significant factor in a subset of the disease (Koliada et al., 2017). These findings were accompanied with the observation of other common changes, such as increases in the Actinobacteria phylum, that may increase energy harvesting and compulsive eating (Koliada et al., 2017).

Consideration of common effects of compositional changes within the gut microbiota across various basal-ganglia associated disorders may shed light on the core functional consequences that may drive basal ganglia pathology. One potential core mechanism may be increases in gut permeability, which may be mediated by several dysbiotic changes in gut microbiota. As discussed, Prevotella may serve as a protective factor against barrier dysfunction, and is lower in abundance in subjects with PD and autism 


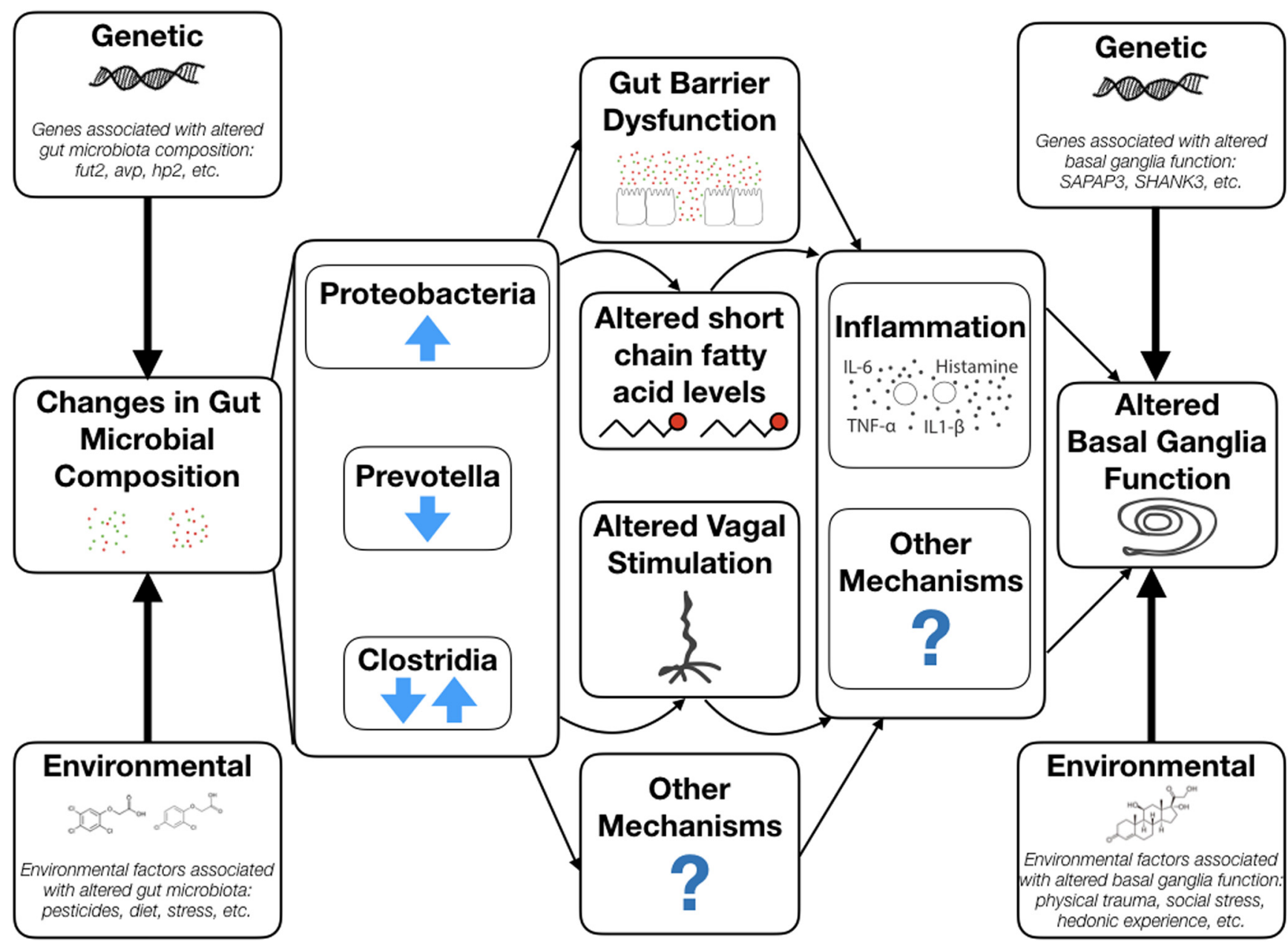

Figure 1. Gut microbial alterations occur within the context of genetic and environmental factors that shape basal ganglia-associated disease susceptibility. These host factors affect both gut microbial composition and basal ganglia function. Common microbial alterations associated with increased disease risk include increases in Proteobacteria, decreases in Prevotella, and alterations in Clostridia, which are all associated with increased gut barrier dysfunction. Other risk factors, such as altered short-chain fatty acid levels, increased vagal activation, and other mechanisms (e.g., the release of other bacterial metabolites) may also result from gut microbial alteration. Increased systemic inflammation and neuro-inflammation are common endpoints of all of these alterations, but other gut-to-brain mechanisms also contribute to basal ganglia disease etiology. Ultimately, gut-derived factors that alter basal ganglia function interact with other preexisting genetic and environmental susceptibility factors to shape specific disease outcomes.

(Kang et al., 2013; Hasegawa et al., 2015; Keshavarzian et al., 2015; Krajmalnik-Brown et al., 2015; Scheperjans et al., 2015; Unger et al., 2016; Bedarf et al., 2017; Strati et al., 2017; Kang et al., 2018; Qiao et al., 2018), but animal models of the disorder also exhibit increases in Prevotella along with increases in gut permeability (Hsiao et al., 2013). Overgrowth of Proteobacteria, which is observed in PD (Forsyth et al., 2011; Keshavarzian et al., 2015; Scheperjans et al., 2015; Unger et al., 2016; Li et al., 2017; Qian et al., 2018) and autism (Williams et al., 2012; Wang et al., 2013), along with obesity (Cani et al., 2007) and cocaine addiction (Volpe et al., 2014), can also stimulate increases in intestinal permeability (Jakobsson et al., 2015), primarily mediated through activation of innate immune receptor TLR4 by its cell surface antigen lipopolysaccharide (Guo et al., 2015). However, here too, noting increases in Proteobacteria are insufficient to infer functional consequences, as even different strains of Escherichia coli, a species in the Proteobacteria phylum, carry lipopolysaccharide molecules with differing levels of immunogenicity, with some serving as TLR4 agonists and others as TLR4 antagonists (Coats et al., 2005). Current high-throughput gut microbiota sequencing efforts, which identify bacteria by a portion of its $16 \mathrm{~S}$ rRNA signature, cannot distinguish between strains, and some se- quence tags fail to discriminate beyond the genus or family level (Fukuda et al., 2016). Assays built to distinguish species and strain-level differences in composition within taxa will allow for investigation of the neurobiological effects of specific microbes with either gnotobiotic models or targeted elimination (e.g., narrow-spectrum bacteriophage-derived treatments such as lysin therapies that eradicate specific bacterial species) (Pastagia et al., 2013). In addition, metabolic profiling of strains exhibiting the most robust compositional changes may provide clues regarding the overarching functional consequences of observed compositional changes.

A specific etiologic trigger, such as gut barrier dysfunction, which may be precipitated by several different changes in bacterial composition, likely interacts with several environmental and genetic risk factors to precipitate specific disease outcomes. This model is highlighted in Figure 1. Increases in gut barrier dysfunction may alter other gut microbial communication pathways to the brain, which may include modifying systemic short-chain fatty acid levels and afferent vagal activity. For example, both rare mutations and ingestion of environmental toxins have been suggested to contribute to disease onset in PD patients, perhaps leading to a greater rate of 
$\alpha$-synuclein misfolding along the vagus nerve (Smith and Parr-Brownlie, 2018; Zeng et al., 2018).

Sex differences in various host systems, such as the immune system (Klein and Flanagan, 2016), may combine with dysbiotic changes in gut microbiota to exacerbate disease outcomes in one or the other sex. For example, bacterial antigens may activate differing types of inflammation in males and females (e.g., generate a more pro-allergic immune profile in males) (Kelly and Gangur, 2009), which promote differing types of neuroinflammation with potentially different behavioral effects. On the other hand, Fields et al. (2018a) revealed that a common microbial antigen elicited similar behavioral but differential immune responses in males and females (Fields et al., 2018a). Only a few studies have directly investigated how gut microbiota and host sex factors interact. For example, one landmark study by Markle et al. (2013) identified robust sex differences in gut microbiota in adult mice and revealed that gut microbiota from males when transferred to females may elevate testosterone levels in females (Markle et al., 2013). The recent National Institutes of Health' mandate to include both female and male subjects in biomedical research should undoubtedly be applied to the study of gut microbiota, which is likely to reveal many more sex-specific effects of gut microbiota on the host.

Gut barrier dysfunction is not the only gut microbiotaassociated factor that has context-specific effects. Short chain fatty acids have been associated with both proinflammatory and anti-inflammatory effects, based on host context (Kuo et al., 2014; Zhang et al., 2016). Furthermore, short chain fatty acid treatment was shown to promote PD motor defects (Sampson et al., 2016) but to protect against sensitization to cocaine (Kiraly et al., 2016). These are not likely the only gut microbiota-associated factors that affect host biology differently based on context. Furthermore, these gut microbial effects are likely to both converge and cancel each other out, so identifying dominant factors within each disease state will be key to identifying prominent mechanisms of action.

From vagal stimulation to systemic breach of gut-derived toxins and from stimulation of systemic inflammation to systemic release of bacterial metabolic byproducts, such as short chain fatty acids, these mechanisms of action can be driven by multiple compositional profiles and can have differential effects based on host biology. Future studies will need to further identify not only compositional differences in gut microbiota associated with health and disease, but also the context-specific functional effects of these microbial alterations. This will serve as a critical step toward developing therapies for basal ganglia-associated disorders targeted at gut microbial manipulation.

\section{References}

Albert U, Aguglia A, Chiarle A, Bogetto F, Maina G (2013) Metabolic syndrome and obsessive-compulsive disorder: a naturalistic Italian study. Gen Hosp Psychiatry 35:154-159. CrossRef Medline

Allison SD, Martiny JB (2008) Colloquium paper: resistance, resilience, and redundancy in microbial communities. Proc Natl Acad Sci U S A 105 [Suppl 1]:11512-11519.

Altieri L, Neri C, Sacco R, Curatolo P, Benvenuto A, Muratori F, Santocchi E, Bravaccio C, Lenti C, Saccani M, Rigardetto R, Gandione M, Urbani A, Persico AM (2011) Urinary p-cresol is elevated in small children with severe autism spectrum disorder. Biomarkers 16:252-260. CrossRef Medline

Argou-Cardozo I, Zeidan-Chulia F (2018) Clostridium bacteria and autism spectrum conditions: a systematic review and hypothetical contribution of environmental glyphosate levels. Med Sci (Basel) 6:E29. CrossRef Medline

Bedarf JR, Hildebrand F, Coelho LP, Sunagawa S, Bahram M, Goeser F, Bork
P, Wüllner U (2017) Functional implications of microbial and viral gut metagenome changes in early stage L-DOPA-naive Parkinson's disease patients. Genome Med 9:39. CrossRef Medline

Bronfeld M, Bar-Gad I (2013) Tic disorders: what happens in the basal ganglia? Neuroscientist 19:101-108. CrossRef Medline

Brown CT, Davis-Richardson AG, Giongo A, Gano KA, Crabb DB, Mukherjee N, Casella G, Drew JC, Ilonen J, Knip M, Hyöty H, Veijola R, Simell T, Simell O, Neu J, Wasserfall CH, Schatz D, Atkinson MA, Triplett EW (2011) Gut microbiome metagenomics analysis suggests a functional model for the development of autoimmunity for type 1 diabetes. PLoS One 6:e25792. CrossRef Medline

Brown TP, Rumsby PC, Capleton AC, Rushton L, Levy LS (2006) Pesticides and Parkinson's disease: is there a link? Environ Health Perspect 114:156164. CrossRef Medline

Bruce-Keller AJ, Salbaum JM, Luo M, Blanchard E 4th, Taylor CM, Welsh DA, Berthoud HR (2015) Obese-type gut microbiota induce neurobehavioral changes in the absence of obesity. Biol Psychiatry 77:607-615. CrossRef Medline

Cakmak YO (2015) Provotella-derived hydrogen sulfide, constipation, and neuroprotection in Parkinson's disease. Mov Disord 30:1151. CrossRef Medline

Cani PD, Amar J, Iglesias MA, Poggi M, Knauf C, Bastelica D, Neyrinck AM, Fava F, Tuohy KM, Chabo C, Waget A, Delmée E, Cousin B, Sulpice T, Chamontin B, Ferrières J, Tanti JF, Gibson GR, Casteilla L, Delzenne NM, et al. (2007) Metabolic endotoxemia initiates obesity and insulin resistance. Diabetes 56:1761-1772. CrossRef Medline

Chandra R, Hiniker A, Kuo YM, Nussbaum RL, Liddle RA (2017) $\alpha$-Synuclein in gut endocrine cells and its implications for Parkinson's disease. JCI Insight 2:92295. CrossRef Medline

Clarke G, Grenham S, Scully P, Fitzgerald P, Moloney RD, Shanahan F, Dinan TG, Cryan JF (2013) The microbiome-gut-brain axis during early life regulates the hippocampal serotonergic system in a sex-dependent manner. Mol Psychiatry 18:666-673. CrossRef Medline

Coats SR, Pham TT, Bainbridge BW, Reife RA, Darveau RP (2005) MD-2 mediates the ability of tetra-acylated and penta-acylated lipopolysaccharides to antagonize Escherichia coli lipopolysaccharide at the TLR4 signaling complex. J Immunol 175:4490-4498. CrossRef Medline

Cone JJ, Chartoff EH, Potter DN, Ebner SR, Roitman MF (2013) Prolonged high fat diet reduces dopamine reuptake without altering DAT gene expression. PLoS One 8:e58251. CrossRef Medline

Desbonnet L, Clarke G, Shanahan F, Dinan TG, Cryan JF (2014) Microbiota is essential for social development in the mouse. Mol Psychiatry 19:146148. CrossRef Medline

Desbonnet L, Clarke G, Traplin A, O'Sullivan O, Crispie F, Moloney RD, Cotter PD, Dinan TG, Cryan JF (2015) Gut microbiota depletion from early adolescence in mice: implications for brain and behaviour. Brain Behav Immun 48:165-173. CrossRef Medline

Diao J, Burré J, Vivona S, Cipriano DJ, Sharma M, Kyoung M, Südhof TC, Brunger AT (2013) Native alpha-synuclein induces clustering of synaptic-vesicle mimics via binding to phospholipids and synaptobrevin2/VAMP2. eLife 2:e00592. CrossRef Medline

Diaz Heijtz R, Wang S, Anuar F, Qian Y, Björkholm B, Samuelsson A, Hibberd ML, Forssberg H, Pettersson S (2011) Normal gut microbiota modulates brain development and behavior. Proc Natl Acad Sci U S A 108:3047-3052. CrossRef Medline

Dinan TG, Borre YE, Cryan JF (2014) Genomics of schizophrenia: time to consider the gut microbiome? Mol Psychiatry 19:1252-1257. CrossRef Medline

Duncan SH, Lobley GE, Holtrop G, Ince J, Johnstone AM, Louis P, Flint HJ (2008) Human colonic microbiota associated with diet, obesity and weight loss. Int J Obes 32:1720-1724. CrossRef Medline

Enaud R, Vandenborght LE, Coron N, Bazin T, Prevel R, Schaeverbeke T, Berger P, Fayon M, Lamireau T, Delhaes L (2018) The mycobiome: a neglected component in the microbiota-gut-brain axis. Microorganisms 6:E22. CrossRef Medline

Enomoto A, Niwa T (2007) Roles of organic anion transporters in the progression of chronic renal failure. Ther Apheresis Dialysis 11 [Suppl 1]: S27-S31.

Fields CT, Chassaing B, Paul MJ, Gewirtz AT, de Vries GJ (2018a) Vasopressin deletion is associated with sex-specific shifts in the gut microbiome. Gut Microbes 9:13-25. CrossRef Medline

Fields CT, Chassaing B, Castillo-Ruiz A, Osan R, Gewirtz AT, de Vries GJ 
(2018b) Effects of gut-derived endotoxin on anxiety-like and repetitive behaviors in male and female mice. Biol Sex Differ 9:7. CrossRef Medline

Figee M, Pattij T, Willuhn I, Luigjes J, van den Brink W, Goudriaan A, Potenza MN, Robbins TW, Denys D (2016) Compulsivity in obsessivecompulsive disorder and addictions. Eur Neuropsychopharmacol 26: 856-868. CrossRef Medline

Finegold SM, Molitoris D, Song Y, Liu C, Vaisanen ML, Bolte E, McTeague M, Sandler R, Wexler H, Marlowe EM, Collins MD, Lawson PA, Summanen P, Baysallar M, Tomzynski TJ, Read E, Johnson E, Rolfe R, Nasir P, Shah H, et al (2002) Gastrointestinal microflora studies in late-onset autism. Clin Infect Dis 35:S6-S16. CrossRef Medline

Finegold SM, Summanen PH, Downes J, Corbett K, Komoriya T (2017) Detection of clostridium perfringens toxin genes in the gut microbiota of autistic children. Anaerobe 45:133-137. CrossRef Medline

Forsyth CB, Shannon KM, Kordower JH, Voigt RM, Shaikh M, Jaglin JA, Estes JD, Dodiya HB, Keshavarzian A (2011) Increased intestinal permeability correlates with sigmoid mucosa alpha-synuclein staining and endotoxin exposure markers in early Parkinson's disease. PLoS One 6:e28032. CrossRef Medline

Franco-Obregón A, Gilbert JA (2017) The microbiome-mitochondrion connection: common ancestries, common mechanisms, common goals. mSystems 2:e00018-17. CrossRef Medline

Fröhlich EE, Farzi A, Mayerhofer R, Reichmann F, Jacan A, Wagner B, Zinser E, Bordag N, Magnes C, Fröhlich E, Kashofer K, Gorkiewicz G, Holzer P (2016) Cognitive impairment by antibiotic-induced gut dysbiosis: analysis of gut microbiota-brain communication. Brain Behav Immun 56: 140-155. CrossRef Medline

Fukuda K, Ogawa M, Taniguchi H, Saito M (2016) Molecular approaches to studying microbial communities: targeting the $16 \mathrm{~S}$ ribosomal RNA gene. J UOEH 38:223-232. CrossRef Medline

Gabriele S, Sacco R, Cerullo S, Neri C, Urbani A, Tripi G, Malvy J, Barthelemy C, Bonnet-Brihault F, Persico AM (2014) Urinary p-cresol is elevated in young French children with autism spectrum disorder: a replication study. Biomarkers 19:463-470. CrossRef Medline

Gabriele S, Sacco R, Altieri L, Neri C, Urbani A, Bravaccio C, Riccio MP, Iovene MR, Bombace F, De Magistris L, Persico AM (2016) Slow intestinal transit contributes to elevate urinary $p$-cresol level in Italian autistic children. Autism Res 9:752-759. CrossRef Medline

Gareau MG, Wine E, Rodrigues DM, Cho JH, Whary MT, Philpott DJ, Macqueen G, Sherman PM (2011) Bacterial infection causes stress-induced memory dysfunction in mice. Gut 60:307-317. CrossRef Medline

Geva-Zatorsky N, Sefik E, Kua L, Pasman L, Tan TG, Ortiz-Lopez A, Yanortsang TB, Yang L, Jupp R, Mathis D, Benoist C, Kasper DL (2017) Mining the human gut microbiota for immunomodulatory organisms. Cell 168: 928-943.e11. CrossRef Medline

Gilbert JA, Blaser MJ, Caporaso JG, Jansson JK, Lynch SV, Knight R (2018) Current understanding of the human microbiome. Nat Med 24:392-400. CrossRef Medline

Gray MT, Woulfe JM (2015) Striatal blood-brain barrier permeability in Parkinson's disease. J Cereb Blood Flow Metab 35:747-750. CrossRef Medline

Guo S, Nighot M, Al-Sadi R, Alhmoud T, Nighot P, Ma TY (2015) Lipopolysaccharide regulation of intestinal tight junction permeability is mediated by TLR4 signal transduction pathway activation of FAK and MyD88. J Immunol 195:4999-5010. CrossRef Medline

Hadj-Bouziane F, Benatru I, Brovelli A, Klinger H, Thobois S, Broussolle E, Boussaoud D, Meunier M (2012) Advanced Parkinson's disease effect on goal-directed and habitual processes involved in visuomotor associative learning. Front Hum Neurosci 6:351. CrossRef Medline

Hasegawa S, Goto S, Tsuji H, Okuno T, Asahara T, Nomoto K, Shibata A, Fujisawa Y, Minato T, Okamoto A, Ohno K, Hirayama M (2015) Intestinal dysbiosis and lowered serum lipopolysaccharide-binding protein in Parkinson's disease. PLoS One 10:e0142164. CrossRef Medline

Heintz-Buschart A, Pandey U, Wicke T, Sixel-Döring F, Janzen A, SittigWiegand E, Trenkwalder C, Oertel WH, Mollenhauer B, Wilmes P (2018) The nasal and gut microbiome in Parkinson's disease and idiopathic rapid eye movement sleep behavior disorder. Mov Disord 33:8898. CrossRef Medline

Hill-Burns EM, Debelius JW, Morton JT, Wissemann WT, Lewis MR, Wallen ZD, Peddada SD, Factor SA, Molho E, Zabetian CP, Knight R, Payami H (2017) Parkinson's disease and Parkinson's disease medications have distinct signatures of the gut microbiome. Mov Disord 32:739-749. CrossRef Medline

Hoban AE, Stilling RM, Moloney G, Shanahan F, Dinan TG, Clarke G, Cryan JF (2018) The microbiome regulates amygdala-dependent fear recall. Mol Psychiatry 23:1134-1144. CrossRef Medline

Holmqvist S, Chutna O, Bousset L, Aldrin-Kirk P, Li W, Björklund T, Wang ZY, Roybon L, Melki R, Li JY (2014) Direct evidence of Parkinson pathology spread from the gastrointestinal tract to the brain in rats. Acta Neuropathol 128:805-820. CrossRef Medline

Hsiao EY, McBride SW, Hsien S, Sharon G, Hyde ER, McCue T, Codelli JA, Chow J, Reisman SE, Petrosino JF, Patterson PH, Mazmanian SK (2013) Microbiota modulate behavioral and physiological abnormalities associated with neurodevelopmental disorders. Cell 155:1451-1463. CrossRef Medline

Ignacio A, Fernandes MR, Rodrigues VA, Groppo FC, Cardoso AL, AvilaCampos MJ, Nakano V (2016) Correlation between body mass index and faecal microbiota from children. Clin Microbiol Infect 22:258.e1-e8. CrossRef Medline

Iovene MR, Bombace F, Maresca R, Sapone A, Iardino P, Picardi A, Marotta R, Schiraldi C, Siniscalco D, Serra N, de Magistris L, Bravaccio C (2017) Intestinal dysbiosis and yeast isolation in stool of subjects with autism spectrum disorders. Mycopathologia 182:349-363. CrossRef Medline

Jakobsson HE, Rodríguez-Piñeiro AM, Schütte A, Ermund A, Boysen P, Bemark M, Sommer F, Bäckhed F, Hansson GC, Johansson ME (2015) The composition of the gut microbiota shapes the colon mucus barrier. EMBO Rep 16:164-177. CrossRef Medline

Jousset A, Bienhold C, Chatzinotas A, Gallien L, Gobet A, Kurm V, Küsel K, Rillig MC, Rivett DW, Salles JF, van der Heijden MG, Youssef NH, Zhang X, Wei Z, Hol WH (2017) Where less may be more: how the rare biosphere pulls ecosystems strings. ISME J 11:853-862. CrossRef Medline

Jung TD, Jung PS, Raveendran L, Farbod Y, Dvorkin-Gheva A, Sakic B, Surette MG, Szechtman H (2018) Changes in gut microbiota during development of compulsive checking and locomotor sensitization induced by chronic treatment with the dopamine agonist quinpirole. Behav Pharmacol 29:211-224. CrossRef Medline

Kang DW, Park JG, Ilhan ZE, Wallstrom G, Labaer J, Adams JB, KrajmalnikBrown R (2013) Reduced incidence of prevotella and other fermenters in intestinal microflora of autistic children. PLoS One 8:e68322. CrossRef Medline

Kang DW, Ilhan ZE, Isern NG, Hoyt DW, Howsmon DP, Shaffer M, Lozupone CA, Hahn J, Adams JB, Krajmalnik-Brown R (2018) Differences in fecal microbial metabolites and microbiota of children with autism spectrum disorders. Anaerobe 49:121-131. CrossRef Medline

Kannarkat GT, Boss JM, Tansey MG (2013) The role of innate and adaptive immunity in Parkinson's disease. J Parkinsons Dis 3:493-514. CrossRef Medline

Kelly C, Gangur V (2009) Sex disparity in food allergy: evidence from the PubMed database. J Allergy (Cairo) 2009:159845. CrossRef Medline

Keshavarzian A, Green SJ, Engen PA, Voigt RM, Naqib A, Forsyth CB, Mutlu E, Shannon KM (2015) Colonic bacterial composition in Parkinson's disease. Mov Disord 30:1351-1360. CrossRef Medline

Kiraly DD, Walker DM, Calipari ES, Labonte B, Issler O, Pena CJ, Ribeiro EA, Russo SJ, Nestler EJ (2016) Alterations of the host microbiome affect behavioral responses to cocaine. Sci Rep 6:35455. CrossRef Medline

Klein SL, Flanagan KL (2016) Sex differences in immune responses. Nat Rev Immunol 16:626-638. CrossRef Medline

Kohl S, Heekeren K, Klosterkötter J, Kuhn J (2013) Prepulse inhibition in psychiatric disorders-apart from schizophrenia. J Psychiatr Res 47:445452. CrossRef Medline

Koliada A, Syzenko G, Moseiko V, Budovska L, Puchkov K, Perederiy V, Gavalko Y, Dorofeyev A, Romanenko M, Tkach S, Sineok L, Lushchak O, Vaiserman A (2017) Association between body mass index and Firmicutes/Bacteroidetes ratio in an adult Ukrainian population. BMC Microbiol 17:120. CrossRef Medline

Krajmalnik-Brown R, Lozupone C, Kang DW, Adams JB (2015) Gut bacteria in children with autism spectrum disorders: challenges and promise of studying how a complex community influences a complex disease. Microb Ecol Health Dis 26:26914. CrossRef Medline

Kuo SM, Chan WC, Hu Z (2014) Wild-type and IL10-null mice have differential colonic epithelial gene expression responses to dietary supplementation with synbiotic Bifidobacterium animalis subspecies lactis and inulin. J Nutr 144:245-251. CrossRef Medline 
Leclercq S, Mian FM, Stanisz AM, Bindels LB, Cambier E, Ben-Amram H, Koren O, Forsythe P, Bienenstock J (2017) Low-dose penicillin in early life induces long-term changes in murine gut microbiota, brain cytokines and behavior. Nat Commun 8:15062. CrossRef Medline

Ley RE, Bäckhed F, Turnbaugh P, Lozupone CA, Knight RD, Gordon JI (2005) Obesity alters gut microbial ecology. Proc Natl Acad Sci U S A 102:11070-11075. CrossRef Medline

Ley RE, Turnbaugh PJ, Klein S, Gordon JI (2006) Microbial ecology: human gut microbes associated with obesity. Nature 444:1022-1023. CrossRef Medline

Li Q, Zhou JM (2016) The microbiota-gut-brain axis and its potential therapeutic role in autism spectrum disorder. Neuroscience 324:131-139. CrossRef Medline

Li W, Wu X, Hu X, Wang T, Liang S, Duan Y, Jin F, Qin B (2017) Structural changes of gut microbiota in Parkinson's disease and its correlation with clinical features. Sci China Life Sci 60:1223-1233. CrossRef Medline

Liu B, Fang F, Pedersen NL, Tillander A, Ludvigsson JF, Ekbom A, Svenningsson P, Chen H, Wirdefeldt K (2017) Vagotomy and Parkinson disease: a Swedish register-based matched-cohort study. Neurology 88:19962002. CrossRef Medline

MacFabe DF, Cain NE, Boon F, Ossenkopp KP, Cain DP (2011) Effects of the enteric bacterial metabolic product propionic acid on object-directed behavior, social behavior, cognition, and neuroinflammation in adolescent rats: relevance to autism spectrum disorder. Behav Brain Res 217:4754. CrossRef Medline

Markle JG, Frank DN, Mortin-Toth S, Robertson CE, Feazel LM, RolleKampczyk U, von Bergen M, McCoy KD, Macpherson AJ, Danska JS (2013) Sex differences in the gut microbiome drive hormone-dependent regulation of autoimmunity. Science 339:1084-1088. CrossRef Medline

Martirosian G, Ekiel A, Aptekorz M, Wiechula B, Kazek B, Jankowska-Steifer E, Józwiak J, Moskalewski S (2011) Fecal lactoferrin and clostridium spp. in stools of autistic children. Anaerobe 17:43-45. CrossRef Medline

Mazmanian SK, Liu CH, Tzianabos AO, Kasper DL (2005) An immunomodulatory molecule of symbiotic bacteria directs maturation of the host immune system. Cell 122:107-118. CrossRef Medline

Merkx-Jacques A, Coors A, Brousseau R, Masson L, Mazza A, Tien YC, Topp E (2013) Evaluating the pathogenic potential of environmental Escherichia coli by using the Caenorhabditis elegans infection model. Appl Environ Microbiol 79:2435-2445. CrossRef Medline

Million M, Angelakis E, Maraninchi M, Henry M, Giorgi R, Valero R, Vialettes B, Raoult D (2013) Correlation between body mass index and gut concentrations of Lactobacillus reuteri, Bifidobacterium animalis, Methanobrevibacter smithii and Escherichia coli. Int J Obes (Lond) 37:14601466. CrossRef Medline

Minato T, Maeda T, Fujisawa Y, Tsuji H, Nomoto K, Ohno K, Hirayama M (2017) Progression of Parkinson's disease is associated with gut dysbiosis: two-year follow-up study. PLoS One 12:e0187307. CrossRef Medline

Moore CF, Panciera JI, Sabino V, Cottone P (2018) Neuropharmacology of compulsive eating. Philos Trans R Soc Lond B Biol Sci 373.

Neufeld KM, Kang N, Bienenstock J, Foster JA (2011) Reduced anxiety-like behavior and central neurochemical change in germ-free mice. Neurogastroenterol Motil 23:255- 264:e119. CrossRef Medline

Nishino R, Mikami K, Takahashi H, Tomonaga S, Furuse M, Hiramoto T, Aiba Y, Koga Y, Sudo N (2013) Commensal microbiota modulate murine behaviors in a strictly contamination-free environment confirmed by culture-based methods. Neurogastroenterol Motil 25:521-528. CrossRef Medline

Parracho HM, Bingham MO, Gibson GR, McCartney AL (2005) Differences between the gut microflora of children with autistic spectrum disorders and that of healthy children. J Med Microbiol 54:987-991. CrossRef Medline

Pascale A, Marchesi N, Marelli C, Coppola A, Luzi L, Govoni S, Giustina A, Gazzaruso C (2018) Microbiota and metabolic diseases. Endocrine 61: 357-371. CrossRef Medline

Pastagia M, Schuch R, Fischetti VA, Huang DB (2013) Lysins: the arrival of pathogen-directed anti-infectives. J Med Microbiol 62:1506-1516. CrossRef Medline

Patrick RP, Ames BN (2015) Vitamin D and the omega- 3 fatty acids control serotonin synthesis and action: 2. Relevance for ADHD, bipolar disorder, schizophrenia, and impulsive behavior. FASEB J 29:2207-2222. CrossRef Medline

Petrov VA, Saltykova IV, Zhukova IA, Alifirova VM, Zhukova NG, Dorofeeva
YB, Tyakht AV, Kovarsky BA, Alekseev DG, Kostryukova ES, Mironova YS, Izhboldina OP, Nikitina MA, Perevozchikova TV, Fait EA, Babenko VV, Vakhitova MT, Govorun VM, Sazonov AE (2017) Analysis of gut microbiota in patients with Parkinson's disease. Bull Exp Biol Med 162: 734-737. CrossRef Medline

Plaza-Díaz J, Ruiz-Ojeda FJ, Vilchez-Padial LM, Gil A (2017) Evidence of the anti-inflammatory effects of probiotics and synbiotics in intestinal chronic diseases. Nutrients 9:E555. CrossRef Medline

Popa SL, Dumitrascu DL (2015) Anxiety and IBS revisited: ten years later. Clujul Med 88:253-257. CrossRef Medline

Poretsky R, Rodriguez RL, Luo C, Tsementzi D, Konstantinidis KT (2014) Strengths and limitations of 16S rRNA gene amplicon sequencing in revealing temporal microbial community dynamics. PLoS One 9:e93827. CrossRef Medline

Posserud I, Stotzer PO, Björnsson ES, Abrahamsson H, Simrén M (2007) Small intestinal bacterial overgrowth in patients with irritable bowel syndrome. Gut 56:802-808. CrossRef Medline

Proença JT, Barral DC, Gordo I (2017) Commensal-to-pathogen transition: one-single transposon insertion results in two pathoadaptive traits in Escherichia coli-macrophage interaction. Sci Rep 7:4504. CrossRef Medline

Pulikkan J, Maji A, Dhakan DB, Saxena R, Mohan B, Anto MM, Agarwal N, Grace T, Sharma VK (2018) Gut microbial dysbiosis in Indian children with autism spectrum disorders. Microb Ecol. Advance online publication. Retrieved Mar. 21, 2018. doi: 10.1007/s00248-018-1176-2. CrossRef Medline

Qian Y, Yang X, Xu S, Wu C, Song Y, Qin N, Chen SD, Xiao Q (2018) Alteration of the fecal microbiota in Chinese patients with Parkinson's disease. Brain Behav Immun 70:194-202. CrossRef Medline

Qiao Y, Wu M, Feng Y, Zhou Z, Chen L, Chen F (2018) Alterations of oral microbiota distinguish children with autism spectrum disorders from healthy controls. Sci Rep 8:1597. CrossRef Medline

Rabot S, Membrez M, Bruneau A, Gérard P, Harach T, Moser M, Raymond F, Mansourian R, Chou CJ (2010) Germ-free C57BL/6J mice are resistant to high-fat-diet-induced insulin resistance and have altered cholesterol metabolism. FASEB J 24:4948-4959. CrossRef Medline

Rosenbaum M, Knight R, Leibel RL (2015) The gut microbiota in human energy homeostasis and obesity. Trends Endocrinol Metab 26:493-501. CrossRef Medline

Sampson TR, Debelius JW, Thron T, Janssen S, Shastri GG, Ilhan ZE, Challis C, Schretter CE, Rocha S, Gradinaru V, Chesselet MF, Keshavarzian A, Shannon KM, Krajmalnik-Brown R, Wittung-Stafshede P, Knight R, Mazmanian SK (2016) Gut microbiota regulate motor deficits and neuroinflammation in a model of Parkinson's disease. Cell 167:1469 1480.e12. CrossRef Medline

Scheperjans F, Aho V, Pereira PA, Koskinen K, Paulin L, Pekkonen E, Haapaniemi E, Kaakkola S, Eerola-Rautio J, Pohja M, Kinnunen E, Murros K, Auvinen P (2015) Gut microbiota are related to Parkinson's disease and clinical phenotype. Mov Disord 30:350-358. CrossRef Medline

Schwiertz A, Taras D, Schäfer K, Beijer S, Bos NA, Donus C, Hardt PD (2010) Microbiota and SCFA in lean and overweight healthy subjects. Obesity 18:190-195. CrossRef Medline

Sender R, Fuchs S, Milo R (2016) Revised estimates for the number of human and bacteria cells in the body. PLoS Biol 14:e1002533. CrossRef Medline

Shaaban SY, El Gendy YG, Mehanna NS, El-Senousy WM, El-Feki HSA, Saad K, El-Asheer OM (2017) The role of probiotics in children with autism spectrum disorder: a prospective, open-label study. Nutr Neurosci 2017: 1-6. CrossRef Medline

Shultz SR (2014) Propionic acid animal model of autism. In: Comprehensive guide to autism (Patel V, Martin C, eds). New York: Springer.

Shultz SR, MacFabe DF, Ossenkopp KP, Scratch S, Whelan J, Taylor R, Cain DP (2008) Intracerebroventricular injection of propionic acid, an enteric bacterial metabolic end-product, impairs social behavior in the rat: implications for an animal model of autism. Neuropharmacology 54: 901-911. CrossRef Medline

Shultz SR, Macfabe DF, Martin S, Jackson J, Taylor R, Boon F, Ossenkopp KP, Cain DP (2009) Intracerebroventricular injections of the enteric bacterial metabolic product propionic acid impair cognition and sensorimotor ability in the Long-Evans rat: further development of a rodent model of autism. Behav Brain Res 200:33-41. CrossRef Medline

Smith LM, Parr-Brownlie LC (2018) A neuroscience perspective of the gut 
theory of Parkinson's disease. Eur J Neurosci. Advance online publication. Retrieved Feb. 15, 2018. doi: 10.1111/ejn.13869. CrossRef Medline

Son JS, Zheng LJ, Rowehl LM, Tian X, Zhang Y, Zhu W, Litcher-Kelly L, Gadow KD, Gathungu G, Robertson CE, Ir D, Frank DN, Li E (2015) Comparison of fecal microbiota in children with autism spectrum disorders and neurotypical siblings in the Simons simplex collection. PLoS One 10:e0137725. CrossRef Medline

Song M, Martinowich K, Lee FS (2017) BDNF at the synapse: why location matters. Mol Psychiatry 22:1370-1375. CrossRef Medline

Song Y, Liu C, Finegold SM (2004) Real-time PCR quantitation of clostridia in feces of autistic children. Appl Environ Microbiol 70:6459-6465. CrossRef Medline

Strati F, Cavalieri D, Albanese D, De Felice C, Donati C, Hayek J, Jousson O, Leoncini S, Renzi D, Calabrò A, De Filippo C (2017) New evidences on the altered gut microbiota in autism spectrum disorders. Microbiome 5:24. CrossRef Medline

Sudo N, Chida Y, Aiba Y, Sonoda J, Oyama N, Yu XN, Kubo C, Koga Y (2004) Postnatal microbial colonization programs the hypothalamicpituitary-adrenal system for stress response in mice. J Physiol 558:263275. CrossRef Medline

Sun MF, Shen YQ (2018) Dysbiosis of gut microbiota and microbial metabolites in Parkinson's disease. Ageing Res Rev 45:53-61. CrossRef Medline

Surowka AD, Krygowska-Wajs A, Ziomber A, Thor P, Chrobak AA, Szczerbowska-Boruchowska M (2015) Peripheral vagus nerve stimulation significantly affects lipid composition and protein secondary structure within dopamine-related brain regions in rats. Neuromolecular Med 17:178-191. CrossRef Medline

Svensson E, Horváth-Puhó E, Thomsen RW, Djurhuus JC, Pedersen L, Borghammer P, Sørensen HT (2015) Vagotomy and subsequent risk of Parkinson's disease. Ann Neurol 78:522-529. CrossRef Medline

Tremlett H, Bauer KC, Appel-Cresswell S, Finlay BB, WaubantE (2017) The gut microbiome in human neurological disease: a review. Ann Neurol 81:369-382. CrossRef Medline

Turnbaugh PJ, Ley RE, Mahowald MA, Magrini V, Mardis ER, Gordon JI (2006) An obesity-associated gut microbiome with increased capacity for energy harvest. Nature 444:1027-1031. CrossRef Medline

Uemura N, Yagi H, Uemura MT, Hatanaka Y, Yamakado H, Takahashi R (2018) Inoculation of alpha-synuclein preformed fibrils into the mouse gastrointestinal tract induces Lewy body-like aggregates in the brainstem via the vagus nerve. Mol Neurodegener 13:21. CrossRef Medline
Unger MM, Spiegel J, Dillmann KU, Grundmann D, Philippeit H, Bürmann J, Faßbender K, Schwiertz A, Schäfer KH (2016) Short chain fatty acids and gut microbiota differ between patients with Parkinson's disease and age-matched controls. Parkinsonism Relat Disord 32:66-72. CrossRef Medline

Volkow ND, Wang GJ, Fowler JS, Telang F (2008) Overlapping neuronal circuits in addiction and obesity: evidence of systems pathology. Philos Trans R Soc Lond B Biol Sci 363:3191-3200. CrossRef Medline

Volkow ND, Wang GJ, Tomasi D, Baler RD (2013) The addictive dimensionality of obesity. Biol Psychiatry 73:811-818. CrossRef Medline

Volpe GE, Ward H, Mwamburi M, Dinh D, Bhalchandra S, Wanke C, Kane AV (2014) Associations of cocaine use and HIV infection with the intestinal microbiota, microbial translocation, and inflammation. J Stud Alcohol Drugs 75:347-357. CrossRef Medline

Vuong HE, Hsiao EY (2017) Emerging roles for the gut microbiome in autism spectrum disorder. Biol Psychiatry 81:411-423. CrossRef Medline

Wang L, Christophersen CT, Sorich MJ, Gerber JP, Angley MT, Conlon MA (2013) Increased abundance of Sutterella spp. and Ruminococcus torques in feces of children with autism spectrum disorder. Mol Autism 4:42. CrossRef Medline

Williams BL, Hornig M, Parekh T, Lipkin WI (2012) Application of novel PCR-based methods for detection, quantitation, and phylogenetic characterization of Sutterella species in intestinal biopsy samples from children with autism and gastrointestinal disturbances. mBio 3:e00261-11. Medline

Yang NJ, Chiu IM (2017) Bacterial signaling to the nervous system through toxins and metabolites. J Mol Biol 429:587-605. CrossRef Medline

Yano JM, Yu K, Donaldson GP, Shastri GG, Ann P, Ma L, Nagler CR, Ismagilov RF, Mazmanian SK, Hsiao EY (2015) Indigenous bacteria from the gut microbiota regulate host serotonin biosynthesis. Cell 161:264-276. CrossRef Medline

Zeng XS, Geng WS, Jia JJ, Chen L, Zhang PP (2018) Cellular and molecular basis of neurodegeneration in Parkinson disease. Front Aging Neurosci 10:109. CrossRef Medline

Zhang Q, Wu Y, Wang J, Wu G, Long W, Xue Z, Wang L, Zhang X, Pang X, Zhao Y, Zhao L, Zhang C (2016) Accelerated dysbiosis of gut microbiota during aggravation of DSS-induced colitis by a butyrate-producing bacterium. Sci Rep 6:27572. CrossRef Medline 